\title{
Contemporary trends in party organization: revisiting intra-party democracy
}

\section{Gabriela Borz and Kenneth Janda}

The study of party organization has gained a new momentum during the last few years. A new wave of studies not only have restated the importance of this concept for party politics, but also expanded the number of and breadth of datasets available for political scientists. From edited books which mostly offer chapters based single cases, the study of party organization has moved towards large comparative studies and 'big data' projects. Within this recent scholarly trend we bring a fresh theoretical and empirical approach to party organization. The studies in this special issue cover both old and new concepts in party organization and bring new data sets to the research community. In what follows we review the state of the field, outline our contribution and conclude with open questions for research.

First and foremost, we believe that party organization should occupy an important place in comparative party research agenda. Theoretically, political scientists are already moving away from a pure deterministic approach whereby organization is seen only as an effect of environmental conditions. The field of party politics should also consider parties' strategic decisions of adopting organizational changes in order to pursue their goals. This special issue brings together a group of articles from different comparative research projects on contemporary party organization. The topics under investigation relate to intra-party democracy and to specific organizational aspects such as access to a party's decision-making processes, candidate selection, party membership, intra-party conflicts and mergers, and their implications for democracy.

\section{Advances in party organization theory}

The literature offers no clear definition of party organization, but the common understanding is that it covers the organizational structure of a political party from its basic organisational units (Duverger, 1954: 17-60) to the top leadership and the power relations across these structures.

Writings on party organization developed without drawing much from organizational theory. Excepting works such as Janda (1983) and Borz and de Miguel (2017), few studies take inspiration from that literature. On the other side, organization theory developed separately without making much reference to party organization studies. Schlesinger (2013) is the exception of a chapter in the Handbook of Organizations (March, 2013). Organization theory however recognized the need for an interdisciplinary approach and also noticed the "lag in communication between disciplines" while stating that "organizations cannot be explained by a single theory" (Hatch 1997: 4). Organizational theory as a field has very similar interests to party theory. Some of its core concepts are about the environment of organization, strategy and goals, technology, organizational social structure, organizational culture and structure of organizations (Hatch 1997; Mintzberg, 1990). The themes of organizational decision-making, conflict, control and ideology in organizations as well as organizational change are well developed across various approaches such as the modernist (rational choice), symbolic-interpretative (qualitative) or the postmodern approach (critical organization theory). Party theorists should build on these approaches.

Duverger developed structural typologies which were later criticized for "attempting a premature correlation between the structure and the social bases of parties" (Sartori 2005). Katz and Mair (1995: 18) in their cartel thesis talked about 'models of party organization' (elite party, mass party, catch-all party), each model being associated with a type of democracy. Besides the nature of 
membership and the relationship between members and party elite, their models were allencompassing and made reference to the distribution of political resources, electoral competition and party competition, party campaigning, party communication, relation with the civil society and the state. In other words, their typology included not only the party structure but also its relation with the political and social environment.

Different strands in the party organization literature were mainly inspired by Duverger's conceptual framework and emphasized single characteristics of party organization. Centralization of power, organizational articulation, direct and indirect structure were concepts developed by Duverger in 1954. Other concepts such as institutionalization or organizational complexity have been developed by Panebianco $(1988)$. Janda's earlier work $(1980,1983)$ built on organization theory and proposed distinctive dimensions of internal party organization: degree of organization (complexity of structural differentiation) and centralization of power (location and distribution of authority), coherence (congruence in the attitudes and behaviour of party members) and involvement (participation in party activities). In line with this differentiation, Ignazi (2001: 12) defined party organization as "an arena of conflicts whose basic stake is "power", that is, control over crucial resources that allows a group - a dominant coalition - to take authoritative legitimate decisions for all and affecting everybody'. From here followed discussions about hierarchical or stratarchical patterns of organizational relations within a party (Carty 2004).

Significant inroads have been made by party scholars interested mainly in one specific part of party organization such as membership (Scarrow, 2005; van Haute and Gauja, 2015) or candidate selection (Rahat , 2009; Rahat and Hazan, 2001). Perhaps one of the most developed contributions to the field came from the area of party organizational change. Katz and Mair (1992) made an important contribution by presenting various descriptive indicators of party change from 1960 to 1990 across 12 Western Democracies. Party rules, party membership, party finance were among the indicators used in their "data handbook." It however provided only a qualitative description of the data which made it user-unfriendly for comparative quantitative format for further analysis. Generalist theories on party organizational change made significant advances with the work of Harmel and Janda (1994), Harmel (2002), Harmel et al (1995) and Gauja (2017). Gauja specified that reform of party organization made publicly is different from party change seen as an evolutionary or incremental processes. In the six countries examined (United Kingdom, Germany, France, Australia and New Zeeland) Gauja (2017: 4) showed that "parties' perceptions of the social trends in which they operate shape reform agendas". Among the reform initiatives observed by the author were the introduction of primaries, the changing meaning of party membership, issues-based online policy development, and community organizing campaigns. Her cases however were old established democracies which also happen to have the highest level of plebiscitary intra-party democracy (Pogunke et al 2016).

The field of party organization is still in need for large comparative studies. There are very few comparative empirical studies to date with a specific focus on party organization. Janda and King (1985) tested Duverger's propositions on 147 parties in 53 countries using 1960 data from Janda's International Comparative Political Parties Project. Scarrow et al (2017) led a new data collection project based on official documents such as party statutes across 25 countries from Latin America Asia and Europe. Borz and de Miguel (2017) focused on party organization by using the Party Unity Expert Survey across 22 European Countries. Other recent data collection efforts are less comparative in scope and present analyses of parties in the same country (Italy) such as Ceron (2015), or a few countries (France and Germany), such as Greene and Haber (2015) who analysed speeches at party congresses in order to measure the level of intra-party disagreement. 
Components of party organization have been linked to important phenomena in political science, which speaks to the importance of the field. Party organization is important for party change (Harmel and Janda 1994, Schumacher et al 2013), party electoral success (Greene and Haber 2015, Tavits 2011, Janda and Coleman 1998, Ishyiama 2001), party system change (Janda 1990), political participation (Kernell 2013), political descentralization (Meguid 2008) or party nationalization (Borz and de Miguel 2017; Chhibber and Suryanarayan 2014).

Recent contributions relate to the consequences of party development and party decline in terms of low legitimacy, low membership and low trust in parties. The new party organization studies concentrate their attention on membership (van Haute and Gauja 2015), reform of party organization different from party change seen as an evolutionary or incremental processes (Gauja 2017), candidate selection (Pilet and Cross 2014), factionalism (Boucek 2012, Ceron 2015), intraparty conflict (Greene and Huber 2015), factionalism, centralization and party unity (Borz and de Miguel 2017), and splits (Ibenskas 2017).

\section{The need for conceptual clarifications}

Some conceptual confusion related to party organization still persists in the party literature and needs to be addressed. The problem applies to the concept of inclusiveness or inclusion. Some authors use it with the meaning of inclusion of members in decision-making via voting while others use it as inclusion of members in decision-making via consultations. Although important distinctions has been made by Rahat and Hazan (2010), one should avoid equating decentralization of party organization with inclusiveness. We also argue against this practice as decentralization may include several aspects of decision-making from general strategies, agenda setting or distribution of resources which are not being captured by member inclusiveness.

Equally, many studies refer to party cohesion, discipline and unity as being the same thing (Andeweg and Thomassen 2011, Hazan 2006). This creates two common problems in the literature. The first one relates to the definitions of these three concepts and the second to the measurement advanced for them. Often, one step is overlooked when defining the concepts, and most scholars, instead of offering a conceptual clarification and definition, refer directly to measurements. The concept of party unity is used to refer to observable behavior (Stecker 2015) such as the MPs' vote inside the legislature. Most of the time, the concept of unity is used interchangeably with that of party discipline and party cohesion, all being presumed to mean roll-call vote unity as measured by the Rice index (Dewan and Spirling 2011; Desposato 2005). The problem lies in the use of roll-call votes as a measurement for the above concepts, when in fact roll-call votes are mainly a behavioral expression and do not necessarily imply similarity in attitudes. The argument can be expanded to concepts such as intra-party democracy and grass roots democracy which are also being used interchangeably. In addition, sometimes intra-party democracy is equated with decentralization which is only one (and narrow) aspect of democratic practices. 


\section{Party Organization and intra-party democracy}

There has been much fascination with the concept of intra-party democracy lately. It became more popular as it started to be implemented in various ways by parties. Green parties have been found to exhibit high levels of intra-party democracy. They were followed closely by Social Democrats, while Conservatives registered average levels of assembly intra-party democracy (Poguntke et al 2016: 672). Variation across party families is not surprising as Harmel and Janda (1994: 265) placed intra-party democracy ('representation/participation of members') as one of four possible primary goals of a political party alongside 'vote maximising, office maximizing and policy/ideology advocacy'. The importance of party democracy as a goal is expected to vary across parties but also within parties across time depending on electoral or other party strategic goals.

Reduced legitimacy is invoked as the main reason why more attention is given to party internal democracy. This is why various parties make efforts to repair the broken links with the electorate and party members and activists. Gauja (2017:5) showed that political parties' organizational reform becomes part of a 'broader rhetoric of democratization, of re-engagement, and of modernization delivered to diverse audiences - both internal and external to the party.' Later in this special issue, Ignazi claims, "Parties were 'in tune with society' during the industrial era prior to WWII and immediately after it but, 'by the end of the 20th century [however] parties became unfit to the postindustrial and postmodern society."

Whilst conceptualisations of intra-party democracy are useful, they should be carefully related to theories of democracy. An index which includes participation, competition, representation, responsiveness and transparency (Rahat and Shapira 2017) might be too broad, whilst another index which focuses only on inclusion of members in electing the leader and the candidates might be too narrow for an account of democratic practices. We already know that electoral authoritarianism coexists with free elections (Schedler 2006). As the party elite are the agenda setters, the outcome of the electoral inclusion can be manipulated (Cross and Pilet 2015, Katz 2013). In fact, it was noticed early on (Katz and Mair, 1995) that giving members more rights is a sign of giving party leaders more autonomy, especially from the party's middle ranks.

Researchers should bear in mind what type of democracy they relate to and whether typologies of intra-party democracy have a positive or negative implication for the political system as a whole (see Teorell 1999). Is intra-party democracy equally effective and important for party elite as for the party members and voters? Katz (2013: 49) suggested that forces outside party organization 'have made partisan involvement less attractive to citizens' and hence we should not expect intra-party democracy to be a miraculous remedy which brings back 'normality'.

Whilst democracy as a concept has different interpretations, the same concept applied to party organization risks to bring confusion to the field. Internal democracy may be a function of a party's size in the legislature and on the ground, hence different parties may prefer different types of internal democracy being implemented depending on their goals. It is important to note that such concept does not receive equal attention in organization theory, partly because the question of legitimacy was not raised with the same intensity, even if one can easily find equal signs of mistrust in various international organizations or cross-national business organizations.

In drawing conclusions about party organization, more attention should be paid to the party as unit of analysis and not to countries. Differences among parties within countries are equally important as 
differences across countries. In their recent study, Poguntke et al. (2016) discussed two types of intra-party democracy: assembly (i.e. inclusiveness of party decision making via discussions, exchange of arguments within party organs and assemblies of all members) and plebiscitary (i.e. member ballots for programme writing and personnel selection). Even if the two concepts are associated they found more evidence of the former than of the latter across the 19 countries in their sample.

Questions remain about which definition of democracy researchers and parties have in mind when they talk about intra-party democracy. Democratic theory has made significant empirical advances (Varieties of Democracy, 2017) and intra-party democracy should follow similar systematic empirical routes. Most importantly has intra-party democracy, as implemented so far, the expected effects for parties themselves and also for the overall party system and political system? Conceptualizations of intra-party democracy based on inclusion of members in selecting the leaders or candidates only runs the danger of placing too much emphasis on particular theories of democracy (i.e., direct or deliberative) without elaborating on the long term implications for the state level democracy.

\section{Party organization on paper and in reality}

The balance between the formal and informal dimension of party organization requires more attention in comparative studies. Are organizational rules implemented as they are on paper or simply overlooked? This question has important implications for the data used in research and for the robustness of findings. Some parties may be very democratic on paper but very authoritarian in practice.

The internal organizational arrangements can be traced from legal documents in the shape of party statutes or party laws. These offer a formal state of the art whilst text analyses of speeches, party surveys or expert surveys can provide additional information about party internal affairs. What this tells us is that the field needs a combination of the above methods when assessing the internal arrangements of parties.

\section{This issue's contribution}

This special issue presents empirical analyses based on new original data sets. All papers offer comparative analyses of party organization across parties and across countries from Western and Eastern Europe but also from South Korea and the European Parliament. The six contributions in this issue use original first-hand data from expert surveys across Europe, surveys of party members in South Korea, elite surveys across Europe, and interviews with members of the European Parliament.

Theoretically, this special issue answers some of the open questions outlined above. The common theme across most articles is the 'controversial' relevance and contemporary use of intra-party democracy in representative democracies. In "The four knights of intra-party democracy: A rescue for party delegitimation," Ignazi offers a relevant theoretical discussion of the need, major components, and consequences of intra-party democracy. The strong message from his article is that inclusion is not enough for democracy to exist inside a party. Pluralism, deliberation and diffusion are also key democratic components. The Rudig and Sajuria article, "Green Party members and grassroots democracy: A comparative analysis," explores the degree and importance of grassroots democracy for green party members. Even if Green parties exhibit the highest level of plebiscitary democracy (cf Poguntke et al 2016), Rudig and Sajuria find that only those members involved in current social movements attribute high importance to intra-party democracy. This ultimately raises the question whether members of other parties (which do not have associated social movements) attribute equal significance to intra-party democratic practices. 
Another very important question about the effects of intra-party democracy is whether it can improve activism and hence nurture political participation as advocated by many studies. Against expectations, Koo's article, "Can Intra-party democracy save party activism? Evidence from Korea," finds that, even in conditions of increased party membership, Korean members who value intraparty democratic practices are less active. Henceforth, in this case, intra-party democracy did not foster or increased the level of activism amongst party members.

The increased usage of informal organizational practices across parties in European parties is a subject that that requires more attention from party scholarship. In "When political parties' actions speak louder than words: Formal and informal processes of candidate selection for European elections," Kelbel examines the formal and informal norms for candidate selection in European elections and the reasons behind the increased usage of the latter. The author finds that 'dominant party actors have indeed adopted practices that allow them to remain or become in charge.' In other words, informality may turn against democratic procedures adopted by parties such as open candidate selection.

As we know that party members in general are not descriptively representative of the general voting population (van Haute and Gauja 2015) an interesting question that arises is if parties with high IPD have members who are more representative of the voting population than those with low IPD. Achury et al., in "Net membership costs and the representativeness of party members," present patterns of party membership in 10 parliamentary democracies and find that inclusiveness could favour representation. In other words, the use of intra-party ballots may attract more representative members than parties which offer no inclusion benefits.

Moving the discussion to party organizational change, one issue for consideration is party mergers not only at the national but at the European level. In "Forging friendships: Europarties and party cooperation in Central and Eastern Europe, explaining party mergers in the European Parliament," Ibenskas explores the reasons behind party mergers in the European Parliament. He contends that structural and organizational institutionalisation in the most important Europarties allows them to influence party mergers in the European Parliament. The mechanism behind mergers is the provision of benefits conditional on party cooperation in national politics and through socialising and persuading the party elites.

Various questions for further research remain. Will intra-party democracy in its various forms contribute to substantive and descriptive representation at the system level? Should parties find alternative routes to intra-party democracy in order to regain legitimacy? How much informality is involved in the screening of candidates before party members are involved in the process of selection? Are all party members across the system supportive of intra-party democracy? What is the link between intra-party democracy, party factions, splits and party mergers? Other very important questions are about the competing organizational strategies which parties may have to adopt in different arenas depending on their goals. In relation to this, how important is party organization in the policy-making process and in the governance process overall? Such questions should occupy another generation of party scholars. 
Author biography:

Gabriela Borz is a lecturer in Politics at the University of Strathclyde, Glasgow, United Kingdom. She specializes in party organization, party regulation, constitutionalism, representation, EU governance.

Kenneth Janda is Payson S. Wild Professor Emeritus of Political Science at Northwestern

University. A co-founder and past editor of Party Politics, he has written extensively on the crossnational analysis of political parties and is co-author of a leading text on American government and politics. 


\section{References}

Andeweg, Rudy B. and Thomassen, Jacques (2011) 'Pathways to party unity: Sanctions, loyalty, homogeneity and division of labour in the Dutch parliament', Party Politics 17(5): 655-672.

Boucek, Francoise (2012) Factional Politics: How Dominant Parties Implode or Stabilize. London: Palgrave Macmillan.

Borz, Gabriela and Carolina de Miguel (2017) 'Organizational and Ideological strategies for Nationalization: Evidence from European Parties' British Journal of Political Science. 1-28.

Carty, Kenneth R. (2005) 'Parties as Franchise systems. A Stratarchical Organizational Imperative' Party Politics 10(1): 5-24.

Carty, Kenneth R. (2013) 'Are Political Parties meant to be Democratic?' In W. Cross and R. Katz (eds.), The Challenges of Intra-Party Democracy. Pp. 11-26 Oxford: Oxford University Press.

Ceron, Andrea (2015) 'The Politics of Fission: Analysis of Faction Breakaways among Italian Parties (1946-2011)', British Journal of Political Science (2):121-139.

Chhibber, Pradeep K. and Pavithra Suryanarayan (2014) 'Party Organization and party proliferation in India.' Party Politics 20(4): 489-505.

Cross, W. and Pilet, J.-B. (2015) 'Parties, Leadership Selection and Intra-Party Democracy'. In W. Cross and J. B. Pilet (eds.), The Politics of Party Leadership. Pp. 165-73. Oxford: Oxford University Press.

Desposato, Scott W. (2005) 'Correcting for small group inflation of roll-call cohesion scores', British Journal of Political Science 35: 731-744.

Dewan, Torun and Spirling, Arthur (2011) 'Strategic opposition and government cohesion in Westminster democracies', American Political Science Review 105: 337-358.

Duverger, Maurice (1954) Political Parties Their Organization and Activity in the Modern State. Methuen: Wiley.

Gauja Anika (2017) Party Reform: The Causes, Challenges, and Consequences of Organizational Change. Oxford: Oxford University Press.

Greene, Zachary and Matthias Haber (2015) 'Leadership Competition and Disagreement at Party National Congresses', British Journal of Political Science (2):1-22.

Harmel, Robert (2002) Party Organizational Change: Competing Explanations? In Political Parties in the New Europe: Political and Analytical Challenges, ed. Kurt Richard Luther and Ferdinand Muller Rommel. Pp. 119-143. Oxford: Oxford University Press.

Harmel, Robert and Kenneth Janda (1994) 'An Integrated Theory of Party Goals and Party Change' Journal of Theoretical Politics 6(3): 259-287. 
Harmel, Robert, Uk Heo , Alexander Tan \& Kenneth Janda (1995) Performance, leadership, factions and party change: An empirical analysis, West European Politics,18(1): 1-33.

Hatch, Mary Jo (1997) Organization Theory. Oxford University Press.

Hazan, Reuven Y. (2006) Does cohesion equal discipline? Towards a conceptual delineation. In:

Hazan RY (ed.) Cohesion and Discipline in Legislatures, pp. 1-11. New York: Routledge.

Ibenskas, Raimondas (2017) 'Electoral competition after party splits', Political Science Research and Methods. Forthcoming.

Ignazi, P. (2001) 'From Brokers to Dealers: The Fate of Political Parties'. Paper presented to the ECPR2001 Conference, University of Kent at Canterbury.

Ishiyama, John T. (2001) Party Organization and the Political Success of the Communist Successor Parties." Social Science Quarterly 82(4): 844-864.

Janda, Kenneth and Desmond S. King (1985) 'Formalizing and Testing Duverger's Theories on Political Parties', Comparative Political Studies 18:139-169.

Janda, Kenneth and Tyler Colman (1998) 'Effects of Party Organization on Performance during the 'Golden Age' of Parties', Political Studies 46:611-632.

Janda, Kenneth (1980) A Cross-national Survey of Political Parties. New York: The Free Press.

Janda, Kenneth (1983) 'Cross-National Measures of Party Organizations and Organizational Theory', European Journal of Political Research 11: 319-332.

Janda, Kenneth (1990) 'Toward a Performance Theory of Change in Political Parties' Paper presented at the 12th World Congress of the International Sociological Association, Research Committee 18, Session 4, "Modelling Party Change", Madrid, Spain, July 9-13.

Katz, R. and P. Mair (1995) 'Changing Models of Party Organization and Party Democracy: The Emergence of the Cartel Party', Party Politics 1: 5-28.

Katz, Richard and Peter Mai (eds.) (1992) Party Organizations: A Data Handbook on Party Organizations in Western Democracies, 1960-1990. London: Sage Publications.

Katz, Richard (2013) 'Should We Believe that Improved Intra-Party Democracy Would Arrest Party Decline?' In William P. Cross and Richard S. Katz (eds.), The Challenges of Intra-Party Democracy. Pp 49-64. Oxford: Oxford University Press.

Kernell, Georgia (2013) Political Party Organizations, Civic Representation, and Participation. In Representation: Elections and Beyond, ed. Jack Nagel and Rogers Smith. Pennsylvania: University of Pennsylvania Press.

March, G. James (2013) The Handbook of Organizations. London: Routledge.

Meguid, Bonnie (2008) Institutional Change as Strategy: The Role of Decentralization in Party Competition." Annual Meeting of the American Political Science Association. 
Mintzberg, Henry (1990) The Design School: Reconsidering the Basic Premises of Strategic Management. John Wiley and Sons Limited.

Panebianco, Angelo (1988) Political Parties: Organization and Power. Cambridge: Cambridge University Press.

Poguntke Thomas, Scarrow Susan E and Webb Paul D. (2016) 'Party rules, party resources and the politics of parliamentary democracies: How parties organize in the $21^{\text {st }}$ century', Party Politics 22 (6): 661-678.

Pilet, Jean B. and Cross, William P. (eds.) (2014) The Selection of Political Party Leaders in Contemporary Parliamentary Democracies: A Comparative Study. London: Routledge.

Rahat, Gideon and Reuven Y. Hazan (2001) 'Candidate Selection Methods: An Analytical Framework', Party Politics 7: 297-322.

Rahat, Gideon, Hazan Reuven and Richard Katz (2008) 'Democracy and political parties. On the uneasy relationships between participation, competition and representation', Party Politics 14(6): 663-683.

Rahat, Gideon (2009) 'Which Candidate Selection Method is the Most Democratic?', Government and Opposition 44(1): 68-90.

Rahat, Gideon and Shapira, Assaf (2017) 'An Intra-Party Democracy Index: Theory, Design and a Demonstration', Parliamentary Affairs 70(1): 84-110.

Reuven Y. Hazan and Gideon Rahat (2010) Democracy within Parties. Candidate Selection methods and their Political Consequences. Oxford: Oxford University Press.

Sartori, Giovanni (2005) 'Party Types, Organisation and Functions', West European Politics, 28(1): 532.

Scarrow, Susan (2005) Political Parties and Democracy in Theoretical and Practical Perspectives: Implementing Intra-Party Democracy. Washington: National Democratic Institute for International Affairs.

Scarrow, Susan and Gezgor, Bogdan (2010) 'Declining Memberships, Changing Members? European Political Party Members in a New Era', Party Politics 16(6): 823-43.

Scarrow, Susan; Paul D. Webb \& Thomas Poguntke (eds) (2017) Organizing Political Parties: Representation, Participation, and Power. Oxford: Oxford University Press.

Schlesinger, Joseph A. (2013) "Political Party Organization" in March G. Joseph (ed). Handbook of Organizations. London: Routledge.

Schedler, Andreas (2006) Electoral Authoritarianism: The Dynamics of Unfree Competition. Boulder and London: Lynne Rienner Publishers.

Schumacher, Gijs, Catherine de Vries and Barbara Vis (2013) 'Why Do Parties Change Position? Party Organization and Environmental Conditions', The Journal of Politics (75): 464-477. 
Stecker, Christian (2015) 'How effects on party unity vary across votes' Party Politics 21(5): 791-802.

Tavits, Margit (2011) 'Organizing for Success: Party Organizational Strength and Electoral Performance in Postcommunist Europe', Journal of Politics 74(1): 83-97.

Teorell, Jan (1999) ‘A Deliberative Defence of Intra-Party Democracy', Party Politics 5(3): 363-82.

van Haute, Emilie, and Anika Gauja (eds) (2015) Party Members and Activists. London: Routledge.

Varieties of Democracy (2017) available at https://www.v-dem.net/en/, last accessed October 2017. 